\title{
THE IMPACT OF EU LAW ON NORWEGIAN PRIVATE INTERNATIONAL LAW
}

\author{
GIUDITTA CORDERO-MOSS*
}

\begin{abstract}
Norway is not a EU member state, but is associated to the EU through the European Economic Area (EEA) Agreement. The EEA Agreement extends the single market to Norway, but does not cover the area of judicial cooperation. EU law nevertheless has a considerable significance for Norwegian private international law. On the one hand, Norway has ratified and implemented Lugano Convention, Norwegian courts give consideration to EU private international law, and there is a project of codification which is based on the Rome I and Rome II Regulations. On the other hand, substantive EU law on the single market may have an impact on the applicable law, and thus indirectly on the effectiveness of private international law. In particular, the principles of freedom of movement and of establishment, as well as the principle of legal clarity, proved to have significance for the formulation of choice of law rules for company and labour law.
\end{abstract}

Keywords: freedom of establishment; freedom of movement; legal certainty; choice of law for companies; choice of law for posted workers

DOI: $10.14712 / 23366478.2020 .30$

\section{INTRODUCTION}

Private international law, also known as conflict rules or choice of law rules, ${ }^{1}$ is that branch of the law that deals with choice of the law applicable to an international legal relationship, choice of forum for international disputes, and the recognition and enforcement of foreign decisions. Private international law is traditionally a part of each state's own law. For EU member states, however, large parts of private international law are regulated by EU law.

Norway is not an EU member state. Since 1994, however, Norway has been connected to the EU by the European Economic Area Agreement (the "EEA Agreement"). Broadly speaking, the EEA Agreement extends to Norway (as well as to Iceland and Liechtenstein) the application of EU law provisions relevant to the implementation of the single market. Basically, this means that Norway is committed to apply principles correspond-

* Giuditta Cordero-Moss is professor of private international law, University of Oslo (Norway), arbitrator.

1 Depending on the legal tradition, the terminology «choice of law» may be used to denote the general act of selecting the applicable law on the basis of conflict rules, or the specific conflict rule of party autonomy (i.e., the parties' power to select the applicable law). I use it in the former sense. 
ing to the EU principles on freedom of movement. Some EU regulations, after they have been deemed to be EEA relevant, are directly applicable in Norway. Other EU instruments, particularly directives, need to be implemented through Norwegian legislation.

EU private international law instruments do not fall within the scope of the EEA Agreement. Therefore, as a general rule, private international law in Norway is a matter of national, Norwegian law.

This, however, does not mean that EU private international law is not applied or does not have influence in Norway. As we will see below, there are two ways in which EU law is relevant to Norwegian private international law.

First of all, parts of EU private international law have become applicable through the Lugano Convention, ${ }^{2}$ as well as through isolated choice of law rules contained in instruments that are EEA relevant. The presence in the Norwegian legal system of isolated provisions of EU private international law exercises a significant force of attraction with respect to the remaining areas of Norwegian private international law. This will be discussed in section 2 below.

Secondly, EU substantive law, notably the principles of free movement and of free establishment, may turn out to have an impact on Norwegian choice of law rules. While EU substantive law does not intend to regulate choice of law, it may have an impact when the law designated as applicable by Norwegian choice of law rules contains a substantive regulation that can be deemed to create obstacles to the freedom of movement or to the freedom of establishment. To the extent that the EEA Agreement forbids hindrances to the freedom of movement or of establishment, the application of the applicable substantive law will be restricted. This has an impact on the effectiveness of the conflict rule that designated that law as applicable. This in turn makes it likely that conflict rules will rather be based on a connecting factor that does not create the risk of infringing the principles of the single market. Indirectly, therefore, EU substantive law has an impact on Norwegian choice of law rules. The same applies to the power of Norwegian courts to determine whether to exercise the exception of public policy. These two kinds of impact will be discussed in section 3 below.

\section{THE ROLE OF EU PRIVATE INTERNATIONAL LAW IN NORWAY}

In Norway, conflict rules have traditionally not been codified. Exceptions include the Act on the law applicable to contracts of sale, implementing the 1955 Hague Convention on the Law Applicable to International Sale of Goods, and certain provisions or special statutes implementing obligations under international law, such as the Product Liability Act, implementing the 1973 Hague Convention on the Law Applicable to Products Liability.

Since Norway's accession to the EEA Agreement in 1994, various conflict rules have been incorporated into Norwegian law as part of the implementation of legislative

22007 Convention on jurisdiction and the recognition and enforcement of judgments in civil and commercial matters. 
acts with EEA relevance. While the EEA Agreement does not cover issues of private international law, conflict rules are found in certain directives and regulations which govern different aspects of the single market and therefore have EEA relevance. These conflict rules have been implemented in Norway. Therefore, there are series of conflict rules in areas such as commercial agency and various parts of consumer law. What these EEA-based Norwegian conflict rules lack, however, is a more general private international law framework. In the EU, this is given by regulations such as the Regulation on the law applicable to contractual obligations (so-called Rome I) ${ }^{3}$ and on the law applicable to non-contractual obligations (so-called Rome II). ${ }^{4}$ These Regulations, however, are not covered by the EEA Agreement and therefore do not have direct effect in Norway.

Norway has ratified and incorporated into its law the Lugano Convention on jurisdiction and the recognition and enforcement of judgments in civil and commercial matters. The Lugano Convention contains rules on choice of forum and on the enforcement of civil judgments and mirrors the Brussels I Regulation. ${ }^{5}$ Brussels I applies to EU member states and is part of an integrated system of EU private international law. Other important elements of this EU system are, among others, the mentioned EU Regulations Rome I and Rome II. The Brussels I Regulation is interpreted in light of the Regulations Rome I and Rome II, and vice versa. Since the Lugano Convention has to be interpreted consistently with the Brussels I Regulation, it can be concluded that Rome I and Rome II indirectly have influence on the Lugano Convention and thus on Norwegian private international law.

The field of private international law is thus only partly regulated by statute in Norway, mostly as a result of the implementation in Norwegian law of EU law or of obligations under international law - particularly, the Lugano Convention.

However, choice of law is not regulated systematically in Norwegian law. Until recently, if a matter did not fall within the scope of the few statutory conflict rules, Norwegian courts would apply the so-called individualising method to determine the applicable law. The individualising method prevailing earlier entailed a discretionary assessment of each individual case on the basis of the circumstances as a whole. Legal doctrine has criticised this method for not being sufficiently objective, for not explaining the criteria according to which the applicable law is determined, and for leading to unpredictable results. ${ }^{6}$

In the last decade, the Norwegian Supreme Court has based a number of decisions on principles corresponding to the conflict rules laid down in Rome I and Rome II. This represents a significant departure from earlier case-law. Basically, according to recent Supreme Court practice, unless there is a Norwegian conflict rule with a different content, the applicable law shall be determined using connecting factors corresponding to those contained in EU private international law.

\footnotetext{
Regulation (EC) 593/2008.

Regulation (EC) 846/2007.

The Lugano Convention reflects the Brussels I Regulation in its version of 2001: Regulation (EG) 44/2001.

6 For references, see CORDERO-MOSS, G. Internasjonal privatrett på formuerettens område. Universitetsforlaget, 2013, pp. 77 et seq.
} 
The sources of Norwegian private international law are, thus, fragmented and difficult to ascertain. Where no conflict rules exist pursuant to statute or customary law, newer case-law gives considerable weight to the provisions in Rome I and Rome II. This reduces the legal uncertainty, but only to a certain degree. If the detailed content of Norwegian conflict rules - or even their existence - is difficult to establish, uncertainty arises as to when and to what extent the courts should give weight to the EU regulations. Moreover, giving weight to the EU regulations on choice of law is also associated with some uncertainty, as the regulations are not binding in Norway. Their application is entirely at the court's discretion.

The fact that choice of law is associated with such significant uncertainty is unfortunate in today's society, in which an ever-increasing number of issues have an international dimension and thus necessitate a choice of law. In this context, it may be sufficient to mention increased population mobility - both private and professional - by way of illustration. Increased mobility is creating an ever-larger number of cross-border legal relations, for example in connection with the purchase of goods, purchase of services, transportation of goods and persons, insurance, financing, employment, residential leases, and tort liability. Moreover, the number of commercial cross-border transactions is rising steadily in both the consumer and commercial segments. When the need to assess parties' rights and obligations arises in such situations, it becomes necessary to determine which state's legal system is applicable.

The need to make a choice of law is thus increasingly important in today's society. It would be unfortunate if conflict rules were to be inaccessible, and their application unpredictable. If party rights and obligations are uncertain, this may have a deterrent effect and, at worst, restrict both international activity by Norwegian actors and interest among international parties in investing in Norway or in trading with Norwegian parties.

Further, unpredictability is a cost driver, as it necessitates extensive investigations and may give rise to avoidable disputes. This hinders efficiency and unnecessarily increases transaction costs. As unpredictability makes it necessary to clarify the choice of law on an ad hoc basis, it also imposes an unnecessary burden on the Norwegian court system.

For all the reasons mentioned above, in 2017 the Norwegian Ministry of Justice launched a process that will hopefully lead to a codification of Norwegian choice of law rules for contractual and non-contractual obligations. The Ministry gave me the mandate to prepare a proposal for a statute and the relevant report. One of the questions the Ministry asked me to evaluate was which sources should be used as an inspiration for the Norwegian codification. In particular, the Ministry wished that I examine the advisability of using EU private international law as a model for the Norwegian codification. The proposal and the report were submitted in 2018, and soon thereafter were sent to public consultation. ${ }^{7}$ It is expected that the Ministry will follow up and continue the legislative process.

In the report to the proposal for a statute on choice of law, I examined the relationship between Norwegian and EU private international law. As mentioned above, a series

7 The proposal, report, and result of the public consultation may be found here: https://www.regjeringen.no /no/dokumenter/horing---enpersonsutredning-om-formuerettslige-lovvalgsregler/id2611666/. 
of reasons suggests that the work on a proposal for a Norwegian statute on conflict rules be based on Rome I and Rome II.

As a consequence, the proposal for a Norwegian statute on choice of law for contractual and non-contractual obligations is modelled on the EU Regulations Rome I and Rome II. Should Norwegian choice of rules be codified along the lines of the proposed statute, Norway will have a set of private international law rules coherent with its rules on jurisdiction and with the isolated choice of law rules incorporated in EU instruments on the single market.

However, quite irrespective of the completion of this legislative process, the EU law-inspired conflict rules that are already codified exercise a considerable force of attraction and thus have an impact on other areas. An important example is the impact that the Lugano Convention had on the Norwegian Civil Procedure Act. When this statute was reformed in 2005, the rules on jurisdiction were modelled on the Lugano Convention. The statute is meant to be applied to cases that do not fall within the scope of application of the Lugano Convention, and the legislator was therefore free to independently develop its own rules. However, for the sake of internal harmonization, the rules largely replicated the Lugano Convention rules.

The foregoing shows that EU private international law has a considerable influence on certain areas of Norwegian private international law - either because provisions of EU law are implemented in Norway, or because they are used as a model for Norwegian choice of law rules.

\section{THE ROLE OF EU SUBSTANTIVE LAW}

There is another way in which EU law may have significance for Norwegian private international law. This is a hidden influence that is exercised not by EU conflict rules, but by EU substantive law. If the application of a Norwegian private international law rule leads to the choice of Norwegian law, and Norwegian law creates more burdens for one party than those that that party is subject to under the law of its home country, under certain circumstances the application of Norwegian law may constitute a hindrance to the free movement within the single market. This is particularly true for the provisions stating the freedom of establishment and the freedom of movement within the common market.

Substantive EU law can have an impact on the efficacy of Norwegian private international law rules, and thus induce the application of a connecting factor that leads to results that are coherent with EU substantive law. Below we will see how EU substantive law may influence the formulation of a conflict rule for company law, as well as the exercise of the public policy exception within labour law.

\subsection{COMPANY LAW}

Norwegian company law may have more burdensome requirements than those set forth under, for example, Irish company law. For example, the required capital 
may be higher in Norway. If a company registered in Ireland moves its main seat to Norway, the freedom of establishment imposes that the Irish company be recognized in Norway as a company duly registered in Ireland, and that Norwegian authorities refrain from requesting that this company comply with the higher capital requirements of Norwegian law.

Seen from a private international law point of view, a company is to meet the company law requirements imposed on it by the applicable law, the so-called lex societatis. How to choose the applicable law depends on the connecting factor used in the conflict rule for company law. There is no uniform approach and legal systems are, broadly speaking, divided between the connecting factor of the main seat (also known as the real seat), and the connecting factor of the registration. The former leads to applying the law of the place where the company has its central administration, the latter to the law of the place where the company is registered.

In Norway, there is no codified conflict rule for company law. There is little case-law on the matter, and legal doctrine was traditionally divided between the main seat and the place of registration as possible connecting factors.

These two connecting factors, the place of registration (or, more precisely, the country under the law of which a company is registered) or the place where the main seat is located, are also the two prevailing connecting factors internationally. More recently, some countries have abandoned the main seat theory and have embraced the registration theory. Also in Norway, legal doctrine has gradually turned to prefer the registration theory. ${ }^{8}$

One of the reasons for preferring the registration theory is that it is easier to apply. It is quite easy to ascertain where a company is registered; to the contrary, it may be very difficult to ascertain where a company has its main seat for international companies with, for example, top management functions spread over different countries, or board meetings taking place in different venues or by electronic means.

Furthermore, the very definition of what constitutes the main seat of a company is not necessarily clear. When, a couple of decades ago, a company registered in Norway was evaluating moving the seat of its board of directors to a different country, it found it difficult to ascertain whether it would continue to be subject to Norwegian law or whether Norwegian law would no longer be applicable to it, with the consequence that the company would have been subject to liquidation and related tax liabilities. If the connecting factor for company law had been the place of registration, moving the seat of the board of directors would not have entailed losing nationality, and therefore no liquidation would have been required. If the connecting factor for company law had been the main seat, moving the board would have entailed losing the Norwegian nationality and therefore being subject to liquidation. The company asked the Ministry of Justice to clarify the legal status - the Ministry of Justice does from time to time render opinions on the status of Norwegian law. Although not binding on the courts, these opinions have a considerable persuasive authority.

8 For references, see CORDERO-MOSS, Internasjonal privatrett på formuerettens område, pp. 268 et seq. 
The Ministry of Justice rendered an opinion that analysed all the available sources, and concluded that it was not possible to set out objective, general criteria for when a company which moves the seat of its board out of Norway may be deemed to no longer be subject to Norwegian law. ${ }^{9}$ Among the issues that according to the Ministry were difficult to ascertain was the definition of main seat.

As was mentioned earlier, Norwegian courts have in the recent decades systematically given great significance to the conflict rules set out in EU private international law. The abovementioned unclear situation with respect to the connecting factor for company law is a perfect basis for looking at EU conflict rules. However, EU law does not have a conflict rule for company law. Article 54 of the TFEU, and the corresponding Article 34 of the EEA Agreement, accept all connecting factors, as long as they do not lead to results that restrict the freedom of establishment set out in Article 49 of the TFEU and Article 31 of the EEA Agreement. There is a long series of decisions by the Court of Justice of the European Union (the CJEU), confirming that EU law does not prefer one connecting factor to another, as long as the law designated as applicable does not restrict the freedom of movement.

While EU private international law does not have a preference for one of the connecting factors for company law, EU substantive law forbids the effects of one of the connecting factors, to the extent that the chosen law would restrict the freedom of establishment. As will be seen below, this dichotomy could be misunderstood.

It could be tempting to criticise the CJEU for not being consistent and for preferring sometimes the registration theory and sometimes the main seat theory. In particular, in a series of decisions the CJEU has affirmed the principle that companies are creatures of national law, and that it is up to national law to determine the conditions for the creation, continued existence, and dissolution of a company. ${ }^{10}$ This could be interpreted as an endorsement of the main seat theory, if the country in which a company is registered has the main seat theory. In a series of other decisions, the CJEU has affirmed the principle that a company that is duly registered in a member state may not be imposed more burdensome company law criteria set out in the company law of another member state to which the company moved its main seat. ${ }^{11}$ This could be interpreted as an endorsement of the registration theory.

This interpretation of CJEU case-law, however, would miss the point of this caselaw. In this jurisprudence, the CJEU was not concerned with confirming a specific connecting factor for company law. The CJEU was concerned with safeguarding freedom of establishment. If the registration theory led to the application of a law that did not restrict the freedom, then the choice of the company law designated by the place of registration was approved of. If, in another setting, the main seat theory led to the application of a law that did not restrict the freedom, then the choice of the company law designated by the place of the main seat was approved of. That the CJEU first endorsed the registration theory and then the main seat theory is not a sign if inconsistency. It

9 Norwegian Ministry of Justice, Selskapsrettslige konsekvenser av å flytte et aksjeselskaps ledelse på styrenivå til utlandet, No 1997/11163 E TO/ØØ, dated 06. 01. 1998.

10 C-81/87 (Daily Mail) (para. 19), C-210/06 (Cartesio), C-371/10 (National Grid), E-15/11 (Arcade).

11 C-208/00 (Überseering), C-167-01 (Inspire Art), C-212/07 (Centros). 
simply means that, by circumstances, both theories are compatible with freedom of establishment. In particular, the main seat theory is compatible with freedom of establishment when it is applied in the country of origin of the company, but not necessarily when it is applied in the country of destination.

If the country in which the company is registered intends to move its main seat to another country, and the country of origin has the main seat theory, moving the main seat will mean that the company will no longer be considered as a company subject to the law of the country of origin. This may trigger consequences, such as dissolution and the payment of taxes. ${ }^{12}$ These consequences are not deemed to represent an unacceptable restriction on the freedom of establishment, because the company chose to register in the country of origin and is deemed to have accepted the conditions for its creation, its continued existence, and its dissolution. Among the conditions for continued existence is that the company maintains its main seat in the country of origin. Hence, applying the main seat theory in the country of origin does not lead to effects that are forbidden by EU substantive law.

If the country to which a company intends to move its main seat has the main seat theory, moving the main seat will mean that the country of destination will consider the company as a company subject to the country of destination's law - notwithstanding that the company is registered in another member state. If the company law of the country of destination has a company law with more burdensome requirements than the country of origin, for example it requires a higher capital, the company's freedom to establish itself in the country of destination will be restricted by the requirement to pay a higher capital. This is an unacceptable restriction on the freedom of establishment. Hence, applying the main seat theory in the country of destination may lead to effects that are forbidden by EU substantive law.

A party choosing to create a company under a certain law must accept that law's requirements. Once a company exists under that law, it must be free to establish itself in other member states, with the only limitations that are provided for in the law under which it was registered.

Applying the connecting factor of the main seat in the country of destination, therefore, may lead to effects that are incompatible with the freedom of establishment. Applying the connecting factor of registration, in contrast, complies with the principle, set out by the CJEU, that companies are creatures of national law - irrespective of whether the connecting factor is applied in the country of origin or in the country of destination.

The foregoing shows that EU substantive law, even when it is not meant to regulate private international law matters, has an impact on the effects of conflict rules. EU substantive law does not require member states to embrace the registration theory; however, under certain circumstances, it forbids the effects of the main seat theory when it is exercised in the country of destination. To ensure internal harmony in its private

12 The consequences of losing the nationality of country of origin must, however, comply with other principles of EU substantive law, such as the principles of proportionality and of non-discrimination. This applies also in the eventuality of a company intending to convert into a company subject to another member state's law, see C-378/10 (Vale), E-15/11 (Arcade), C-106/16 (Polbud). 
international law, therefore, it is preferable for a country to adopt the registration theory, whose effects will not be incompatible with EU substantive law. Norwegian legal doctrine seems nowadays to have embraced the place of registration. ${ }^{13}$ However, although it is clearly preferable from a normative point of view, it is not clear whether this reflects the prevailing law. ${ }^{14}$

A further, interesting impact of EU substantive law on Norwegian private international law (and on Norwegian law in general), is connected with the principle of legal certainty. This can be illustrated by a decision rendered by the EFTA Court in a case relating, among other things, to the choice of law for companies. ${ }^{15}$

A Norwegian company had moved its main seat out of the country, but was still registered as a Norwegian company. The question was whether, having moved its main seat, the company could be deemed to have lost its Norwegian nationality, which in turn would have led to consequences in terms of dissolution and taxation. Following the abovementioned case-law by the CJEU, the EFTA Court recalled that companies are creatures of national law. Norway was, therefore, free to apply the main seat theory and to require that the company be dissolved.

However, the EFTA Court invoked the principle of legal certainty, and specified that the criteria according to which the nationality of a company is determined, need to be clear and objective. This criterion is likely to have a significant impact on Norwegian private international law - as was seen above, not only is it not completely clear from the applicable sources whether the applicable connecting factor is registration or the main seat; even more important is that there are no objective and clear criteria to define what is the main seat, as the abovementioned opinion by the Ministry of Justice concluded.

\subsection{LABOUR LAW}

Another area in which EU substantive law may limit the effects of the application of Norwegian private international law is the area of labour law - in particular, in connection with posted workers. The way in which Norwegian law was applied by the Norwegian Supreme Court ${ }^{16}$ was deemed by the EFTA Surveillance Authority, the ESA, to infringe Article 36 of the EEA Agreement on freedom to provide services. ${ }^{17}$ In particular, it was the Supreme Court's evaluation of what represents Norwegian public policy, that was put into question. The ESA issued a formal notice initiating a case against Norway for breach of the EEA Agreement. The case was later closed, ${ }^{18}$ in part

13 See, for references, CORDERO-MOSS, Internasjonal privatrett på formuerettens område, p. 281.

14 In one of the many decisions involving the moving out of Norway of the company Arcade, the Oslo District Court found that the registration theory is clearly preferable. However, it concluded that the prevailing law was still as described by the Ministry of Justice in its opinion of 1998, see TOSLO-2010-147861 UTV-2013-1050.

15 E-15/11 (Arcade). The EFTA Court is a court established to interpret the EEA Agreement. It is, broadly speaking, the EEA parallel to the CJEU.

16 Rt. 2013 s. 238 (STX).

17 ESA Letter of formal notice to Norway concerning the posting of workers dated 25 October 2016, Decision No 191/16/COL.

18 ESA Decision dated 19 December 2018, Decision No 109/18/COL. 
as a consequence of a political compromise that led to some changes in the disputed rules of the EU Directive on posted workers, ${ }^{19}$ and in part due to the amendment of the relevant Norwegian regulation.

The Supreme Court decision was rendered in a dispute between the Confederation of Norwegian Enterprises and the Norwegian state. The Confederation claimed that the Norwegian state infringed the principle of freedom to provide services when it applied a regulation requiring enterprises providing construction services in Norway and using workers posted from abroad to pay to the posted workers a compensation for their board and lodging expenses.

The regulation in question was based on the Statute on General Application of Collective Agreements. ${ }^{20}$ This statute permits an autonomous governmental body, the Tariff Board, ${ }^{21}$ to decide that, in certain sectors, collective labour agreements be applicable to all workers employed in that sector, irrespective of whether the workers or the employers are bound by the collective agreement.

The purpose of the statute is to ensure that foreign workers who work temporarily in Norway have employment conditions that are comparable to Norwegian workers' employment conditions. While this measure may combat dumping practice and the exploitation of foreign workers, it also has the effect of protecting Norwegian employment conditions from foreign competition. Furthermore, it has the effect of restricting the possibility of foreign companies to compete in the Norwegian market if they use posted workers. The use of workers coming from abroad becomes much more expensive than the use of local workers when a collective agreement contains provisions requiring the employer to cover necessary travel expenses upon the commencement and completion of the assignment of a worker and for a reasonable number of journeys home, as well as to pay for board and lodging when performing the work in Norway. This is an obstacle to the free provision of services.

The field of temporary work is subject to the Directive on posted workers, which is EEA relevant and has been implemented in Norway. Under this Directive, employment conditions for workers from a member state who are temporarily employed in another member state shall be subject to the law of the country where the workers normally work (which for brevity I will hereafter define as "home country").

This rule is the result of a political compromise between the work-exporting member states and the work-importing member states. It is assumed that employment conditions in work-exporting states are more favourable to the employer, and that therefore posted workers will be able to be more competitive on the labour market than local workers. This facilitates the export of workforce. Work-exporting countries, therefore, benefit from the rule designating their law as the law applicable to the conditions of employment of their workers who are temporarily employed in another country. Host countries, however, have mixed interests. On the one hand, employers in the host country may

19 Directive 96/71/EC concerning the posting of workers in the framework of the provision of services.

20 Act of 4 June 1993 No 58 relating to general application of collective agreements.

21 For the sake of transparency, I inform that I am a member of the Tariff Board. The Tariff Board's resolutions which were the object of the dispute and of the ESA notice mentioned here were, however, taken before I became a member. 
be interested in benefitting from a cheaper workforce. Therefore, they welcome posted workers who can offer more competitive employment conditions from their home countries. Local employees, in contrast, are interested in maintaining the level of work protection and of benefits that was reached thanks to long-lasting economic development and trade unions activity. Competition from posted workers who accept more restrictive employment conditions may threaten the standard of worker protection prevailing in the host country. Employees in host countries, therefore, would prefer that foreign workers who are temporarily employed in the host country benefit from the same employment conditions as local workers.

The compromise between these opposed interests was found in Article 3 of the Directive. This provision contains an exhaustive list of employment conditions that may be subject to the law of the host country. Among these conditions is the minimum rate of pay.

Among the questions that were decided by the Norwegian Supreme Court, was whether the Collective Agreement's provision on compensation for board and lodging expenses could, pursuant to the General Application Act, also be applied to posted workers. According to the Directive, the issue of compensation for board and lodging expenses has to be governed by the posted worker's home country, unless it can be deemed to fall within the scope of Article 3, for example as being part of the minimum rate of pay.

According to the ESA, ${ }^{22}$ a systematic interpretation of the Directive as it was at the time of the dispute suggested that compensation for board and lodging expenses did not fall within the scope of Article 3 and must thus be subject to the law of the posted workers' home country. The Supreme Court, in contrast, opted for the opposite interpretation, that would have permitted applying the Norwegian regulation extending the Collective Agreement. The Supreme Court, however, did not conclude on this issue, ${ }^{23}$ because it found that in any case compensation for board and lodging expenses fell within the scope of Article 3 No 10 of the Directive - containing a reservation for public policy.

The Norwegian Supreme Court considered the importance that collective negotiations have in Norwegian society. The cooperation of social parties has traditionally been an important characteristic of the Norwegian labour market, based on the acknowledgement that the salary level has had great significance for the development of Norwegian society. ${ }^{24}$ In addition, it has traditionally been considered to be of crucial importance that collective negotiations be carried out first in sectors where competition is free, and that the result of the negotiations in these sectors be applied in protected sectors. The Supreme Court found that this method has traditionally ensured social stability in

22 ESA Formal notice dated 25 October 2016, paras. 38-61.

23 The list of Article 3 was later amended to also include compensation for board and lodging expenses however, only relating to travels within the host member state. The new regulations by the Tariff Board were, in turn, amended to extend only compensation for board and lodging expenses relating to travels within the host member state. Therefore, there was no discrepancy any more between the Directive and the Tariff Board regulation, and the ESA closed the case against Norway.

24 Rt. 2013 s. 258 , para. 159. 
Norway. In fact, this system is so fundamental for the functioning of Norwegian society that it must be considered to represent public policy.

The exception of public policy is a known mechanism in private international law. It permits, in exceptional situations, to disregard specific rules of otherwise applicable law. A condition for the exercise of the public policy exception is that the result of applying the foreign rule would seriously infringe fundamental principles in the court's country. The threshold for applying the public policy exception is very high.

Within EU private international law, the criteria for defining the scope of the public policy exception are a matter of EU law - for example, Article 21 of the Rome I Regulation requires the breach to be manifest, and the preamble explains that the exception may be used in exceptional situations. ${ }^{25}$

The definition of the public policy exception and its effects, therefore, are a matter of EU law. However, the definition of what is the content of public policy is left to the member states. What constitutes a fundamental principle in a certain country is a matter for that country to define.

The same mechanism that is laid down in the Rome I Regulation for contract obligations is applicable in the field of individual employment contracts under the Directive. Thus, the ESA affirmed that: "While the EEA States are still, in principle, free to determine the requirements of public policy in the light of national needs, the notion of public policy may be relied upon only if there is a genuine and sufficiently serious threat to a fundamental interest of society." 26

When the Supreme Court argued that the system of collective labour negotiations is a fundamental characteristic of the Norwegian labour market, and that not being able to apply the Collective Agreement rule on compensation for board and lodging expenses would have seriously undermined the stability of Norwegian society, it exercised the prerogative of national courts to determine what is a fundamental principle in their country.

Admittedly, the Supreme Court seems to have interpreted the public policy exception in a much broader way than what is usual in the field of private international law and, according to the ESA, in the specific context of Article 3 No 10 of the Directive. One of the problematic issues arising out of the exception of public policy is precisely the risk that courts may interpret it too extensively, thus disregarding the foreign applicable law to a larger extent than what the narrow scope of public policy is supposed to permit.

However, the fact remains that it falls within the power of national courts to determine which principles are fundamental in the court's own legal system. The ESA, in contrast, initiated a case for breach of the EEA Agreement on the basis of the Norwegian Supreme Court's application of the public policy exception. The basis for doing so was that the Supreme Court's exercise of the public policy exception would restrict the freedom of movement.

25 Rome I, preamble, para. 37.

26 ESA Formal notice dated 25 October 2016, para. 68. 


\section{CONCLUSION}

The foregoing shows that Norwegian private international law is exposed to multiple influences from EU law - notwithstanding that Norway is not a member state of the EU, and that private international law does not fall within the scope of the EEA Agreement.

On the one hand, there is the influence exercised by EU conflict rules. Some of them are implemented in Norway and are therefore directly applicable. This is the case of conflict rules contained in EU instruments on the single market. The instruments on the single market are relevant to the EEA Agreement and are therefore implemented in Norway, and the conflict rules that may have been included in these instruments find their way into the Norwegian legal system. Another source of the import of EU private international law is the Lugano Convention. Other EU private international law rules are considered to have significance because they give the systematic framework for the EU conflict rules that are implemented in Norway. This is the case of the Rome I and Rome II Regulations, which are significant for the interpretation of the Brussels I Regulation and thus for the Lugano Convention. For the sake of harmonisation of the Norwegian legal system internally, as well as with its neighbouring countries and Europe, EU private international law is therefore deemed to have great significance for Norwegian private international law. A proposal for a statute on choice of law for contractual and non-contractual obligations is largely based on the Rome I and Rome II Regulations.

On the other hand, there is the influence of substantive EU law. This is an indirect influence: EU substantive law is not aimed at imposing connecting factors for designating the applicable law. EU substantive law is concerned with safeguarding and promoting the single market. As the examples of company law and of labour law showed, the application of Norwegian law may, under certain circumstances, represent a restriction on the freedom of establishment or of movement. In these cases, EFTA authorities have reacted to the restrictive effect of applying Norwegian law. This has various indirect effects on Norwegian private international law: choice of law rules for company law need to be formulated in a more objective and predictable way; the connecting factor for company law may not, under certain circumstances, be the company's main seat; and the Norwegian provisions on the general application of collective agreements' regulation of the compensation for board and lodging expenses may not be deemed to represent public policy.

Private international law is, therefore, highly intertwined - not only the different branches of private international law with each other, but also with substantive law.

Professor Dr iuris Giuditta Cordero-Moss

University of Oslo

Giuditta.cordero-moss@jus.uio.no 